\title{
Standardization of penile hemodynamic evaluation through color duplex-doppler ultrasound
}

1. Departamento de Radiologia, Universidade de São Paulo, São Paulo, SP, Brasil. 2. Departamento de Urologia, Universidade Federal do Ceará, Fortaleza, CE, Brasil.

\section{SUMMARY}

INTRODUCTION: The vascular evaluation of the erectile function through Color Duplex-Doppler Ultrasound (CDDU) of the penis can benefit the therapeutic decision-making process. Unfortunately, there is no standard procedure for CDDU conduction, a fact that results in high result-interpretation variability.

OBJECTIVE: The aims of this review are to promote greater standardization during CDDU of the penis and discuss the fundamental principles for its accurate conduction.

METHODS: CDDU is initially conducted with the penis in the flaccid state; the whole penis must be assessed (images at $B$ mode) with a high-frequency linear transducer $(7.5-18 \mathrm{MHz}$ ). Intracavernous injection of vasodilating agents (prostaglandin E1, papaverine, phentolamine) is performed to induce a rigid erection. Serial measurements at different times should be taken during the CDDU session and penile rigidity must be assessed in each evaluation.

RESULTS: It is important to monitor the erection response after the vasoactive agent (hardness scale), and scanning during the best-quality erection should be contemplated. Manual self-stimulation, audiovisual sexual stimulation (AVSS), and vasoactive agent re-dosing protocols must be taken into account to reduce the influence of psychogenic factors and to help the patient to get the hardest erection possible. Such measurements contribute to the maximal relaxation of the erectile tissue, so the hemodynamic parameters are not underestimated.

CONCLUSIONS: CDDU is a relevant specialized tool to assess patients with erectile dysfunction; therefore, this guideline will help to standardize and establish uniformity in its conduction and interpretation, taking into consideration the complexity and heterogeneity of CDDU evaluations of the penis.

KEYWORDS: Erectile dysfunction. Erectile dysfunction/diagnosis. Ultrasonography. Ultrasonography, Doppler.

\section{INTRODUCTION}

Color Duplex-Doppler Ultrasound (CDDU) of the penis was first described by Lue et al. ${ }^{1}$ and remains one of the most important tools available to assess patients with $\mathrm{ED}^{2,3}$. CDDU of the penis is an objective diagnostic method, but it requires specific training. An objective hemodynamic evaluation through CDDU has prognostic importance and helps to choose the best treatment strategy ${ }^{4,5}$. Possible indications for 
CDDU include: young patients with primary ED, pelvic trauma history, drug abuse, pre-operative evaluation for Peyronie's disease, psychogenic ED documentation, and medicolegal situations ${ }^{6}$.

The lack of standardized hemodynamic evaluation through CDDU is one of the main limitations of this $\operatorname{method}^{7}$. It explains the great variability in performing and interpreting penile hemodynamic studies in both clinical practice and scientific studies. These factors have contributed to the fact that CDDU is often considered unreliable, as it may lead to mistaken treatment protocols ${ }^{8}$.

The aim of the present article is to establish standard operational procedures to minimize confounders in order to help predict with reasonable accuracy the etiology of ED. It is also our goal to discuss the basic principles of drug-induced erection.

\section{Basic Principles in Sexual Medicine}

\section{Erection anatomy and physiology}

\section{A. Blood flow and veno-occlusive mechanism}

The erectile tissue is mainly composed of smooth muscle, elastic fibers, and endothelium, which together form the sinusoids of the corpora cavernosa. Arterial supply is achieved through the internal pudendal artery, which branches out and gives origin to the cavernous artery. The venous drainage of the cavernous tissue is performed by a surface and deep vein system; however, the subtunical venules promote blood exit from the intracavernous space during erection.

Blood flow increases during sexual stimulus without changes in systemic blood pressure. The smooth muscle relaxes and expands, as the sinusoids get full of blood. This expansion generates relative venous drainage reduction, mainly because of the passive venoconstriction of the subtunical veins, which triggers the veno-occlusive mechanism. Axial rigidity increases exponentially when the compression of the subtunical venules is complete ${ }^{9}$. There is blood flow in systole, but not in diastole (diastole zero), when ICP becomes equal to the diastolic blood pressure (DBP). In a progressive way, the reverse diastole phenomenon, which is featured by blood inflow in the systole and blood efflux in diastole, happens when ICP is higher than DBP. ICP can eventually be higher than the systolic peak pressure, and this process makes blood inflow in systole minimal or even absent ${ }^{10}$. The correlation between CDDU findings and Doppler velocity is shown in Figure 1.
FIGURE 1. DOPPLER TRACING BEHAVIOR PRESENTING PROGRESSIVE INTRACAVERNOUS PRESSURE (ICP) DURING ERECTION. ICP = INTRACAVERNOUS PRESSURE; DBP = DIASTOLIC BLOOD PRESSURE; SBP = SYSTOLIC BLOOD PRESSURE.

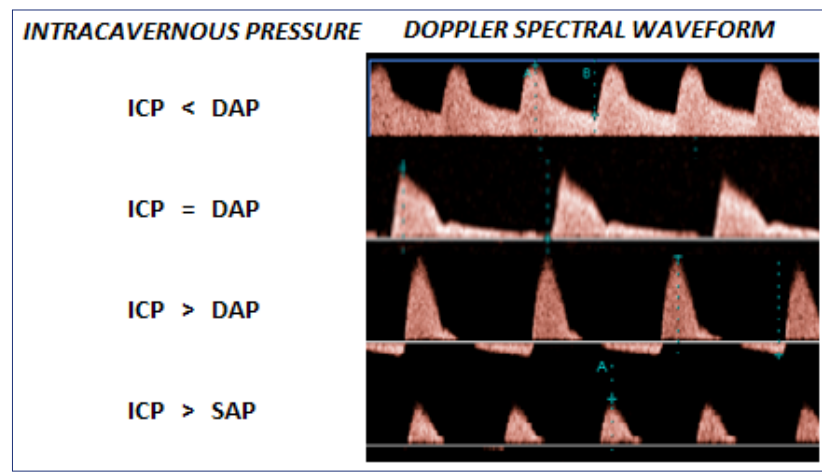

\section{B. Pharmacology}

Oral drugs act through nitric oxide pathways and increase Cyclic GMP concentration inside the muscle cell because they inhibit the enzyme responsible for Cyclic GMP degradation, known as type 5 phosphodiesterase (PDE5) ${ }^{11}$. Intracavernous vasoactive agents act through direct muscle relaxation. The most common agents are papaverine, phentolamine, and prostaglandin.

On the other hand, sympathomimetic agents contract the intracavernous smooth muscle and antagonize the veno-occlusive mechanism of erection. Etilefrine is the medication available in Brasil presenting the greatest selectivity to alpha-receptors, which should be preferred to minimize beta-adrenergic activity.

\section{Clinical evaluation}

Having a basic evaluation is fundamental to exam conduction. Medical history, including comorbidities, medication use, and previous pelvic or retroperitoneal surgery must be questioned. The patient must be asked about his hardest erection, which would be the minimal erection hardness to be obtained during the exam. Information about ED chronology and the permanence of nocturnal erections can be quickly obtained.

\section{Erection Hardness Scales}

The examiner must get used to constantly reassessing erection quality during CDDU sessions through visual evaluation and penis palpation. In order to facilitate this evaluation, there are validated erection quality scales, among them is the EHS (Erection Hardness Score), which is the most common and broadly used. 
It is possible to use a 0-10 erection scale, whose score 6 (or 60\%) corresponds to the minimal hardness for penetration. This decimal scale is easily comprehensible and can be converted into the EHS scale.

\section{Exam Preparation}

CDDU can be performed in clinics and/or hospitals, as long as these facilities are well equipped. The vascular ultrasonography assessment of the penis is dynamic and requires an intracavernous injection (ICI) of vasodilating agents in order to help the patient achieve the hardest erection possible $e^{7,12,13}$. Thus, the examiners must be familiar with the physiology of erection and recognize common confounding factors and artifacts in order to perform an adequate interpretation. Moreover, the examiner must be able to identify and/or treat prolonged erections and priapism caused by ICI.

\section{Technical preparation}

\section{A. About the location}

i. CDDU must be performed in a quiet location, due to the influence of psychological and environmental effects on the erectile response;

ii. Equipment to provide audio-visual sexual stimuli is an interesting tool, because it helps patients to get a harder erection with smaller doses of vasoactive agents;

iii. Medication vials properly stored are required, these include vasoactive agents and sympathomimetics for the eventual need of reversion.

\section{B. About the equipment}

i. Ultrasound device with Doppler;

ii. High-Frequency Linear Transducer (7.5 - 18 $\mathrm{MHz}$;

iii. Device to store the images and a printer.

\section{Exam conduction}

The CDDU exam starts with the penis in a flaccid state. The whole penis must be scanned through longitudinal and cross-sectional images at mode B by using a high-frequency linear transducer (7.5 $18 \mathrm{MHz}$ ). This assessment aims at seeking changes in the eco-texture of both the erectile tissue and the tunica albuginea.

Measurements of the internal diameter of the cavernous arteries (right and left) and, optionally, of the peak systolic velocity (PSV) in the cavernous arteries at spectral Doppler mode can be performed at the beginning of the exam. Although there are some studies presenting good predictive PSV values at flaccid state, the universal consensus lies in conducting CDDU with drug-induced erection ${ }^{14-16}$. In order to do so, it is important to administer vasoactive agents ${ }^{1,5,17}$. There is no consensus about the dose to be administered for erection induction; however, the dose is expected to be the least necessary to generate a hard erection (EHS 4). If such an erection is not possible, at least a bedroom quality erection (BQE) should be obtained, which may require re-dosing of ICI. Therefore, there is no standard dosage to be universally used, because each patient has a different response to intracavernous pharmacotherapy. A re-dosing protocol based on frequent reassessments is able to minimize the adrenergic effect and allows satisfactory relaxation of the smooth muscle. Yet, there is no consensus about the proper medication, dose, and the number of injections at re-dosing ${ }^{18}$.

The transducer position during cavernous artery evaluation can change from the crura to the base of the penis - on its ventral or dorsal aspect. Conceptually, there would be no problem in assessing the cavernous arteries at any point of their extension, since cavernous bodies are tridimensional structures that work as a single cavity. However, some studies have already assessed the influence of transducer position and they have shown that more proximal evaluations overestimate the PSV values, whereas the most distal evaluations underestimate EDVs ${ }^{19}$. Overall, we suggest the readings should be made on the ventral face, close to the penoscrotal junction, in order to avoid artifacts resulting from too proximal or too distal positions.

Step-by-step guide for CDDU examination

A. Turn the ultrasound device on to start the exam; select the transducer and the appropriate configurations.

B. Explain all the steps of the evaluation to the patient and ask his consent to proceed.

C. Instruct the patient to lie on a horizontal dorsal decubitus position and to relax as much as possible.

D. Place the transducer with transmitter gel on the base of the penis to start scanning.

E. Assess the anatomy of the corpus cavernousum and spongiosum, and record any abnormalities in the eco-texture.

F. Take cross-sectional and longitudinal images of both cavernous arteries (at proximal aspect/ 
third of the penile shaft) and report possible anatomic variations. Measure the intraluminal diameter of the left and right cavernous arteries and record the appropriate nomenclature.

G. Use a syringe $(0.5-3 \mathrm{~mL})$ with insulin needle (27-30 gauge, 0.5-in) and hold the penis tight; inject the vasodilating agent in the dorsolateral aspect of the proximal or middle third of the penile shaft, and take it away from the dorsal neural bundle. Press the injection site for 10 seconds in order to avoid agent reflux to surface planes. Register the drug-administration time.

H. AVSS use is recommended, mainly in anxious patients. In order to do so, the patient must stay alone in the examination room during the time to stimulate smooth muscle relaxation ${ }^{7,20}$.

I. Take images of left and right cavernous arteries at mode B. Turn the Doppler mode on, regulate the sample and the angle ( $<60$ degrees) in order to measure the PSV ${ }^{21}$.

J. Repeat the same procedure to both cavernous arteries and distinguish the laterality in the records.

K. It is essential to assess PSV and EDV at the erection peak because these measurements are the most important clinical evaluations. The evaluation is based on the time after the injection, it can also be taken at 5, 10, 15, and 20 minutes, as long as the hardness is assessed - at each new assessment time - for proper interpretation.

L. Take cross-sectional and longitudinal images of the cavernous arteries (similar to step G) at hardness peak or maximum hardness (EHS 4) and measure the intraluminal diameter at both sides. Register the acquired data and the respective laterality.

M. After the exam, ask the patient to wait from 30 minutes to 1 hour to evaluate possible collateral effects caused by the pharmacological induction agent (prolonged painful erection, priapism, discomfort in the area where the drug was injected).

$\mathrm{N}$. If the patient presents a prolonged painful erection, it is worth reversing it in order to avoid priapism. We do not recommend waiting for more than 4 hours to perform the reversion, since prolonged erections for longer than 1 hour can cause edema in the cavernous bodies, a fact that considerably reduces patient's response to sympathomimetic agents and increases the need of aspiration. The administration of an alpha-adrenergic selective agonist (e.g., 1-2 mg etilefrine) in the cavernous body every 5-10 minutes - until completing one full hour - can be adopted for detumescence. Symptoms such as acute hypertension, headache, reflex bradycardia, tachycardia, palpitations, or cardiac arrhythmias must be monitored through a cardiac monitor and serial blood pressure must be taken. In some cases, the patient must be subjected to cavernous body aspiration in order to help detumescence and, consequently, to reduce the amount of administered alpha-adrenergic, as well as to reduce adverse reaction time.

O. The examination report must be detailed and express all calculated and collected data throughout the assessment (mode of report in appendix). Clinical impressions also have to be informed in the report (for example, patient anxiety during the study, among others).

P. Send the patient home and give him overall orientations and warnings (for example, priapism signs) and, whenever necessary, schedule a follow-up visit.

Q. File all images and the report in the patient's medical records.

\section{Interpretation of hemodynamic parameters}

The following parameters are often used in the hemodynamic evaluation of systemic vessels and they are also useful for ED evaluation ${ }^{7,14-16,20}$ : Peak Systolic Velocity (PSV); End Diastolic Velocity (EDV); Resistivity Index (RI); Pre and post diameter of cavernous arteries. The cavernous artery diameter has limited value and has also been questioned due to its incapacity to predict the proper hardness, mainly in patients presenting suspicion of atherosclerosis and increased cardiovascular risk ${ }^{22}$. Changes in intracavernous diameter (sagittal and transverse), as well as in PSV, EDV, and RI can be evaluated in each cavernous artery at different moments. There can be differences in the basal features to find PSV between fast and slow responders.

An objective rigidity evaluation must be routinely performed before each reading of hemodynamic parameters. This approach minimizes false diagnosis of cavernous veno-occlusive dysfunction since similar 
findings are obtained in cases of adrenalin-mediated failure to obtain optimal rigidity ${ }^{10,23}$.

The PSV measurement to assess arterial competence enables researchers to accept values between $25-30 \mathrm{~cm} / \mathrm{s}$ as the lower normality limit ${ }^{3,10}$. A PSV higher than $30 \mathrm{~cm} / \mathrm{s}$ highlights normal arterial flow after proper pharmacological stimulus; on the other hand, a PSV $<25 \mathrm{~cm} / \mathrm{s}$ is a diagnostic of arterial insufficiency. Confirmatory studies based on angiography have shown that a velocity limit higher than $25 \mathrm{~cm} / \mathrm{s}$ leads to $92 \%$ accuracy in arterial integrity diagnostic ${ }^{2,10}$.

EDV and RI measurements bring information about the mechanism of penile veno-occlusion. A EDV > 5 $\mathrm{cm} / \mathrm{s}$ and $\mathrm{RI}<0.75$ show veno-occlusion associated with normal arterial function ${ }^{10,15}$. Lack of specificity for venous leak caused by arterial insufficiency is the main limitation of this exam. Proper arterial inflow with short-duration semi-rigid erection and persistent diastolic flow $>5 \mathrm{~cm} / \mathrm{s}$ (attention to the angle) - at all moments of the study - suggests venous leak ${ }^{10,15}$. However, it is important to be while reporting this condition since it is irreversible and has a great influence on the patient's treatment, mainly because rigidity loss during the exam or suboptimal ICI dosage generates similar traces and can cause pseudo-diagnostics. The literature has demonstrated that up to $50 \%$ of veno-occlusive dysfunction reports are equivocal $^{24}$. Table 1 demonstrates possible CDDU diagnoses according to hemodynamic parameters. Figure 2 shows Doppler ultrasound waveform in different hemodynamic diagnoses.

\section{Recording relevant findings}

Proper data recording evidences high-quality care of patients; this has to be a priority. Images must contain the exam date and patient identification; moreover, anatomical structures must be properly named. It is fundamental to keep permanent files of all exams and medical reports for clinical and legal purposes,

TABLE 1. HEMODYNAMIC CLASSIFICATION BASED ON CAVERNOUS ARTERY VELOCITIES.

\begin{tabular}{l|l|l|l}
$\begin{array}{l}\text { Doppler parameters } \\
\text { Hemodynamics }\end{array}$ & $\begin{array}{l}\text { PSV } \\
(\mathrm{cm} / \mathrm{s})\end{array}$ & EDV $(\mathrm{cm} / \mathrm{s})$ & $\mathrm{RI}$ \\
\hline $\begin{array}{l}\text { Normal } \\
\text { hemodynamics }\end{array}$ & $\geq 30$ & $\begin{array}{l}<5 \\
\text { With preferential } \\
\text { O (zero) or negative }\end{array}$ & $>0.9$ \\
\hline Arterial insufficiency & $<25$ & $<5$ & - \\
\hline $\begin{array}{l}\text { Veno-occlusive } \\
\text { cavernous dysfunction }\end{array}$ & $\geq 30$ & $\geq 6$ & $<0.75$ \\
\hline \begin{tabular}{l} 
Mixed dysfunctions \\
\hline
\end{tabular} & DSV = Peak systolic velocity; EDV = Ending diastolic velocity; RI = Resistant index
\end{tabular}

FIGURE 2. DOPPLER ULTRASOUND WAVEFORM IN DIFFERENT HEMODYNAMIC DIAGNOSES.

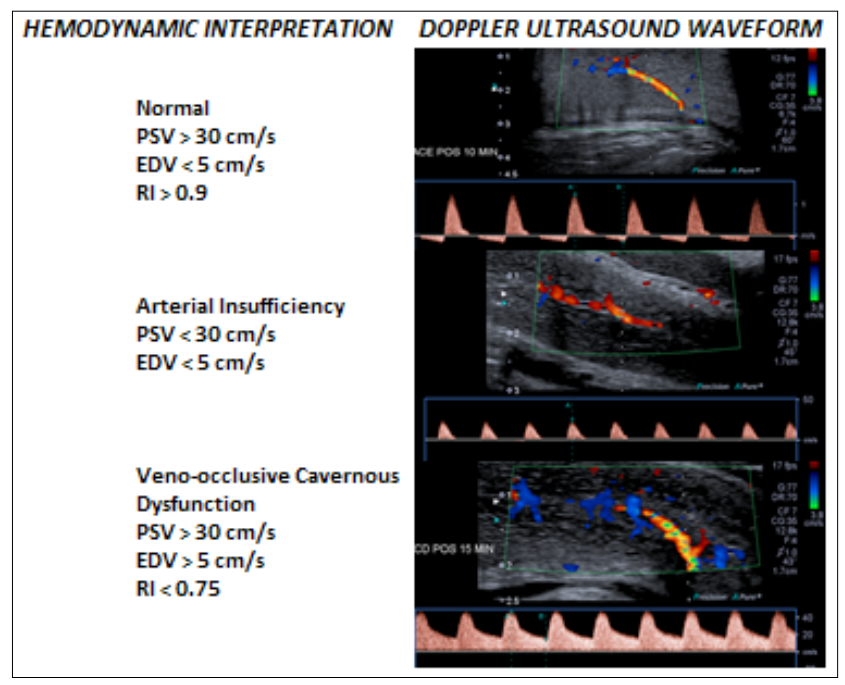

as well as to make a precise description of the following parameters:

1. It is important to record the patient's relevant information such as age, dose, and type of drug used. The following assessed parameters must be recorded, ideally:

i. Longitudinal and cross-sectional diameters of the left and right cavernous arteries before and after pharmacological induction;

ii. PSV, EDV, and RI during different examination times of the two cavernous arteries;

iii. final drug-dose administered during the exam.

2. Data evaluation and interpretation:

i. Hardness data must also be documented during the hemodynamic evaluation of the penis through CDDU.

ii. Structural abnormalities in the penis related to tunica albuginea, corpus cavernous, and spongy (heterogeneity, hyperechoic areas, and plaques), as well as in the arteries, must be reported.

iii. It is necessary to recognize Doppler artifacts such as aliasing, acoustic shadow, mirror image, among others ${ }^{23}$.

iv. Sometimes, it is difficult to properly interpret blood flow direction in some regions of the vascular tree, mainly in bifurcations, ramifications, stenoses, and in areas distal to plaques. Variations in blood flow direction depend on transducer positioning and on the appropriate use of the angle, among others. Thus, the 
examiner must be an expert in the method to avoid wrong evaluations and interpretations ${ }^{25}$.

\section{CONCLUSIONS}

The hemodynamic evaluation of the penis by color Doppler is a very useful tool for a specialized evaluation of ED. Evaluation of hemodynamic velocities without a deep understanding of the erectile mechanism may lead to wrong interpretations and negative consequences to the patient. Examiners must improve their skills in drug-induced erection and hardness scores in order to provide more sophisticated evaluations.

\section{Author's Contribution}

FC, OCS, and EPM were responsible for the initial concept and design. FC and EPM drafted the manuscript. OCS revised it critically for important intellectual content. FC, OCS, and EPM performed the literature review. FC, OCS, and EPM helped revise and edit the final version of the manuscript. All authors read and approved the final manuscript.

\section{RESUMO}

INTRODUÇão: A avaliação vascular da função erétil por meio da ultrassonografia com Doppler colorido do pênis (UDCP) pode trazer benefícios na tomada de decisão. Infelizmente, a falta de padronização na condução de UDCP resulta em alta variabilidade do exame, além de poder comprometer a interpretação dos resultados.

OBJETIVO: Os objetivos desta revisão são promover uma maior padronização durante o UDCP e discutir os princípios fundamentais para sua correta condução e interpretação.

MÉTODOS: O UDCP é conduzido inicialmente com o pênis no estado flácido; todo o pênis deve ser avaliado (imagens no modo B) com um transdutor linear de alta frequência (7,5 -18 MHz). A injeção intracavernosa de agentes vasodilatadores (prostaglandina E1, papaverina, fentolamina) é realizada para induzir uma ereção rígida. Medições seriais em momentos diferentes podem ser realizadas durante a sessão da UDCP e a rigidez peniana deve ser estimada em cada avaliação.

RESULTADOS: É importante monitorar a resposta da ereção após o agente vasoativo (escala de rigidez), bem como realizar avaliação hemodinâmica durante a ereção de melhor qualidade. Os protocolos de estimulação sexual manual e audiovisual (AVSS) e redosagem de agente vasoativo devem ser levados em consideração para reduzir a influência de fatores psicogênicos e ajudar o paciente a obter a ereção mais rígida possível. Tais medidas contribuem para o relaxamento máximo do tecido erétil, de modo que os parâmetros hemodinâmicos não são subestimados.

CONCLUSÕES: O UDCP é uma ferramenta especializada relevante para avaliar pacientes com disfunção erétil; portanto, esta diretriz ajudará a padronizar e estabelecer uniformidade em sua condução e interpretação, se considerarmos a complexidade e a heterogeneidade das avaliações do pênis por UDCP.

PALAVRAS-CHAVE: Disfunção erétil. Disfunção erétil/diagnóstico. Ultrassonografia. Ultrassonografia Doppler.

\section{REFERENCES}

1. Lue TF, Hricak H, Marich KW, Tanagho EA. Vasculogenic impotence evaluated by high-resolution ultrasonography and pulsed Doppler spectrum analysis. Radiology. 1985;155(3):777-81.

2. Hatzimouratidis K, Giuliano F, Moncada I, Muneer A, Salonia A, Verze P. EAU guidelines on erectile dysfunction, premature ejaculation, penile curvature and priapism. European Association of Urology; 2016. [cited 2020 Feb 3]. Available from: https://uroweb.org/wp-content/uploads/EAU-Guidelines-Male-Sexual-Dysfunction-2016.pdf

3. Patel $P$, Masterson T, Ramasamy R. Penile duplex: clinical indications and application. Int J Impot Res. 2019;31(4):298-9.

4. Celik O, Ipekci T, Akarken I, Ekin G, Koksal T. To evaluate the etiology of erectile dysfunction: what should we know currently? Arch Ital Urol Androl. 2014;86(3):197-201.

5. Meuleman EJ, Hatzichristou D, Rosen RC, Sadovsky R. Diagnostic tests for male erectile dysfunction revisited. Committee Consensus Report of the International Consultation in Sexual Medicine. I Sex Med. 2010;7(7):2375-81.

6. Gerbild H, Larsen CM, Graugaard C, Areskoug Josefsson K. Physical activity to improve erectile function: a systematic review of intervention studies. Sex Med. 2018;6(2):75-89.
7. Lee B, Sikka SC, Randrup ER, Villemarette P, Baum N, Hower JF, et al. Standardization of penile blood flow parameters in normal men using intracavernous prostaglandin E1 and visual sexual stimulation. J Urol. 1993; 149(1):49-52.

8. Cavallini G, Maretti C. Unreliability of the duplex scan in diagnosing corporeal venous occlusive disease in young healthy men with erectile deficiency. Urology. 2018;113:91-8.

9. Meldrum DR, Burnett AL, Dorey G, Esposito K, Ignarro LI. Erectile hydraulics: maximizing inflow while minimizing outflow. J Sex Med. 2014;11(5):1208-20.

10. Jung DC, Park SY, Lee JY. Penile Doppler ultrasonography revisited. Ultrasonography. 2018;37(1):16-24.

11. Burnett AL. The science and practice of erection physiology: story of a revolutionary gaseous molecule. Trans Am Clin Climatol Assoc. 2019;130:51-9.

12. Mellinger $B C$, Vaughan $E D \mid$ r. Penile blood flow changes in the flaccid and erect state in potent young men measured by duplex scanning. J Urol. 1990;144(4):894-6.

13. Speel TG, van Langen $H$, Wijkstra $H$, Meuleman EJ. Penile duplex pharmaco-ultrasonography revisited: revalidation of the parameters of the cavernous arterial response. J Urol. 2003;169(1):216-20. 
14. Aversa A, Sarteschi LM. The role of penile color-duplex ultrasound for the evaluation of erectile dysfunction. J Sex Med. 2007;4(5):1437-47.

15. Hsiao W, Shrewsberry AB, Moses KA, Pham D, Ritenour CW. Longer time to peak flow predicts better arterial flow parameters on penile Doppler ultrasound. Urology. 2010;75(1):112-6.

16. Kuo YC, Liu SP, Chen JH, Chang HC, Tsai VF, Hsieh JT. Feasability of a novel audio-video sexual stimulation system: an adjunct to the use of penile duplex Doppler ultrasonography for the investigation of erectile dysfunction. I Sex Med. 2010;7(12):3979-83.

17. Caretta N, Palego P, Roverato A, Selice R, Ferlin A, Foresta C. Age-matched cavernous peak systolic velocity: a highly sensitive parameter in the diagnosis of arteriogenic erectile dysfunction. Int J Impot Res. 2006;18(3):306-10.

18. Ghafoori M, Hoseini K, Shakiba M. Comparison of one-side and bilateral intracavernosal papaverine injection on a Doppler study of the penis. Int I Impot Res. 2009;21(6):382-6.

19. Pagano M|, Stahl PI. Variation in penile hemodynamics by anatomic location of cavernosal artery imaging in penile duplex doppler ultrasound. J Sex Med. 2015;12(9):1911-9.
20. Chung E, De Young L, Brock GB. Penile duplex ultrasonography in men with Peyronie's disease: is it veno-occlusive dysfunction or poor cavernosal arterial inflow that contributes to erectile dysfunction? I Sex Med. 2011;8(12):3446-51.

21. Radparvar JR, Lim G, Chiem AT. Effect of insonation angle on peak systolic velocity variation. Am J Emerg Med. 2019; S0735-6757(19)30072-5. doi: 10.1016/j.ajem.2019.01.050.

22. Shamloul R, Ghanem HM, Salem A, Elnashaar A, Elnaggar W, Darwish H, et al. Correlation between penile duplex findings and stress electrocardiography in men with erectile dysfunction. Int | Impot Res. 2004;16(3):235-7.

23. Bönhof $\mid A, M c L a u g h l i n ~ G$. Artifacts in sonography - part 3. Ultraschall Med. 2018;39(3):260-83

24. Dabaja AA, Teloken P, Mulhall JP. A critical analysis of candidacy for penile revascularization. J Sex Med. 2014;11(9):2327-32.

25. Hügel U, Rosenov A, Baumgartner I, Thalhammer C. Vascular color-coded duplex ultrasound in practice: artifacts. Praxis (Bern 1994). 2019;108(10):679-84. 